IZA DP No. 7245

Lawyers as Agents of the Devil in a Prisoner's Dilemma Game: Evidence from Long Run Play

Orley Ashenfelter

David E. Bloom

Gordon B. Dahl

February 2013 


\title{
Lawyers as Agents of the Devil in a Prisoner's Dilemma Game: Evidence from Long Run Play
}

\author{
Orley Ashenfelter \\ Princeton University \\ and IZA \\ David E. Bloom \\ Harvard University \\ and IZA \\ Gordon B. Dahl \\ University of California, San Diego \\ and IZA \\ Discussion Paper No. 7245 \\ February 2013 \\ IZA \\ P.O. Box 7240 \\ 53072 Bonn \\ Germany \\ Phone: +49-228-3894-0 \\ Fax: +49-228-3894-180 \\ E-mail: iza@iza.org
}

\begin{abstract}
Any opinions expressed here are those of the author(s) and not those of IZA. Research published in this series may include views on policy, but the institute itself takes no institutional policy positions. The IZA research network is committed to the IZA Guiding Principles of Research Integrity.

The Institute for the Study of Labor (IZA) in Bonn is a local and virtual international research center and a place of communication between science, politics and business. IZA is an independent nonprofit organization supported by Deutsche Post Foundation. The center is associated with the University of Bonn and offers a stimulating research environment through its international network, workshops and conferences, data service, project support, research visits and doctoral program. IZA engages in (i) original and internationally competitive research in all fields of labor economics, (ii) development of policy concepts, and (iii) dissemination of research results and concepts to the interested public.
\end{abstract}

IZA Discussion Papers often represent preliminary work and are circulated to encourage discussion. Citation of such a paper should account for its provisional character. A revised version may be available directly from the author. 


\section{ABSTRACT \\ Lawyers as Agents of the Devil in a Prisoner's Dilemma Game: Evidence from Long Run Play ${ }^{*}$}

Do the parties in a typical dispute face incentives similar to those in the classic prisoner's dilemma game? In this paper, we explore whether the costs and benefits of legal representation are such that each party seeks legal representation in the hope of exploiting the other party, while knowing full well that failing to do so will open up the possibility of being exploited. The paper first shows how it is possible to test for the presence of such an incentive structure in a typical dispute resolution system. It then reports estimates of the incentives for the parties to obtain legal representation in wage disputes that were settled by final-offer arbitration in New Jersey. The paper also reports briefly on similar studies of data from discharge grievances, court-annexed disputes in Pittsburgh, and child custody disputes in California. In each case, the data provide evidence that the parties face strong individual incentives to obtain legal representation which makes the parties jointly worse off. Using our New Jersey data, we find that expert agents may well have played a productive role in moderating the biases of their clients, but only early on in the history of the system. Over time, the parties slowly evolved to a non-cooperative equilibrium where the use of lawyers becomes nearly universal, despite the fact that agreeing not to hire lawyers is cheaper and does not appear to alter arbitration outcomes.

JEL Classification: J52, K0

Keywords: prisoner's dilemma, arbitration, lawyers

Corresponding author:

Gordon B. Dahl

University of California, San Diego

9500 Gilman Drive \#0508

La Jolla, CA 92093-0508

USA

E-mail: gdahl@ucsd.edu

\footnotetext{
* The authors are grateful to the Russell Sage and Alfred P. Sloan Foundations for financial support. An early version of this paper, with limited data on arbitration cases in New Jersey, appeared as a 1993 NBER working paper.
} 
“The nickname Prisoner's Dilemma, attributed to A.W. Tucker, derives from the original anecdote used to illustrate the game. Two prisoners, held incommunicado, are charged with the same crime. They can be convicted only if either confesses. Further, if only one confesses, he is set free for having turned state's evidence and is given a reward to boot. The prisoner who has held out is convicted on the strength of the other's testimony and is given a more severe sentence than if he had also confessed. It is in the interest of each to confess whatever the other does. But it is in their collective interest to hold out."

--Rapoport and Chammah (1965)

\section{Introduction}

This paper explores the possibility that the parties to a typical dispute face incentives very similar to those faced by the prisoners in the classic dilemma described above. The goal is to explore the possibility that the costs and benefits of legal representation are structured so that each individual party seeks representation in the hope of exploiting the other party, while knowing full well that failing to do so will open up the possibility of being exploited.

In the prisoner's dilemma the players are faced with incentives that may lead to behavior that is not in the best interests of either party. The incentive structures embedded in such institutions provide a payoff to each party for engaging in noncooperative behavior. The mere existence of such incentives is not enough to produce the prisoner's dilemma, however. In order to produce inefficiency the payoffs to noncooperative behavior must be larger than the costs. Determining whether a particular institution embodies the incentives associated with the prisoner's dilemma thus requires determining whether the individual benefits to engaging in noncooperative behavior are likely to exceed the costs.

The first part of this paper shows how it is possible to test for the presence of an incentive structure like the one in a prisoner's dilemma game in a typical dispute resolution system. The goal is to measure the payoff matrix faced by the parties. Although the analysis is framed in the context of an arbitration system it could equally as well be applied to any dispute resolution 
system, including the court system. The second part of the paper reports estimates of the incentives for the parties to obtain legal representation in wage disputes that were settled by final-offer arbitration in New Jersey. ${ }^{1}$ The paper also reports briefly on similar studies of data from (1) the arbitration of discharge grievances, (2) the arbitration of court-annexed disputes in Pittsburgh, and (3) the settlement of child custody disputes in California. All of these data provide evidence that the parties face strong individual incentives to obtain legal representation. Whether these incentives lead to excessive legal representation that has no social benefit is discussed in the final section of the paper. Using our New Jersey data, we find some evidence that lawyers may well have improved outcomes by moderating client biases early on in the history of the system. However, over time, the parties slowly evolved to a non-cooperative equilibrium where the use of lawyers becomes nearly universal, despite the fact that agreeing not to hire lawyers is cheaper and does not appear to alter arbitration outcomes.

\section{Incentives for Noncooperation}

The theoretical literature on the economics of litigation, particularly game theory applied to law, is extensive. In contrast, there has been less empirical work, consisting of a few experimental papers on game theory and litigation and some empirical work in field settings. ${ }^{2}$ The main contribution of this paper is to lay out a simple model of the role lawyers play in dispute resolution, and empirically test whether the incentives present in such systems generate a prisoner's dilemma.

\footnotetext{
${ }^{1}$ A related, but more technical analysis of New Jersey's arbitration system, can be found in Ashenfelter and Dahl (2012).

${ }^{2}$ For a summary of theoretical models of negotiation and legal services, see Spier (2007). Prominent papers in this literature include Katz (1988), Kerkmeester (1995), P'ng (1983), Reinganum and Wilde (1986), Rong (2011), and Spier (1994). Experimental papers on game theory and litigation include Ashenfelter, Currie, Farber, and Spiegel (1992), Kritikos (2006), and Plott and Coughlan (2002). Greiner and Pattanayak (2012) provide an example of empirical work in a field setting.
} 
We lay out the incentives for noncooperation in the setting of labor disputes, although the discussion could easily be applied to other environments as well. We assume the employer seeks the highest net value added (the value of the workers' output less their costs) consistent with recruiting enough workers, and the union seeks to receive the highest labor costs consistent with the continued viability of the employer. In the typical case where arbitration is used to settle such labor disputes, workers and employers have long term relationships they would like to see continue indefinitely. However, it is necessary to change the terms of the employment agreement as the external labor market changes, and this causes disputes over just how much the compensation of these workers should increase.

To avoid costly strikes, arbitration is sometimes used as the procedure to resolve these compensation disputes. In most labor disputes, and as we model them in this section, the two parties are disagreeing over next year's wage increase, expressed in percent terms. For example, the union may wish for a $6 \%$ increase in wages while the employer may be arguing for a $2 \%$ increase in wages. The arbitrator, as a third entity, has his own idea of what would be a reasonable increase in wages in percent terms; often the arbitrator's preferred wage increase lies somewhere between the demands of the two parties.

It is now widely agreed that if the parties submit their disputes to arbitration, they will be facing some uncertainty over just what wage increase the arbitrator will select (see Ashenfelter and Bloom 1984, Farber and Bazerman 1986, Bloom 1986, Ashenfelter 1987, and Olson, Dell'Omo, and Jarley 1992). Suppose the distribution from which the arbitral awards come has a normal distribution, with mean $u$ and standard deviation $s$. If the old wage rate is $w$ and employment is $e$, then the increase in the wage bill that the parties may expect if they go to arbitration without employing agents is weu (i.e., the old wage multiplied by the number of 
employees multiplied by the expected percent increase in wages as decided on by the arbitrator).

Now let us consider the payoff to the union if the union employs an agent, but the employer does not. Suppose that by employing an agent the union may expect to improve the mean of the distribution from which the arbitrators' awards are drawn by the quantity $a$. This shift is depicted in Figure 1. It follows that if the union proceeds to arbitration and employs an agent it will expect to receive the wage bill we $(u+a)$. Assuming the agent's fee is $x^{\prime}$, the net wage bill expected if an agent is retained is $w e(u+a)-x^{\prime}$. The increase in the wage bill that the union may expect from employing an agent is thus wea- $\chi^{\prime}$, and the proportionate increase is $a-x$ (where $x=x^{\prime} / w e$, the proportion that legal costs are of the wage bill.)

The employer's net value added if the union engages an agent, but the employer does not, is $z$-we $(u+a)$, where $z$ represents the value of the union's work. The employer's net value added if neither party engages an agent is z-weu. The increase in the net value added to the employer as a proportion of the wage bill is thus - $a$ for the case where the union employs an agent and the employer does not.

The upper right hand corner of the matrix in Table 1 contains the payoffs to the employer (the first entry) and the union (the second entry) as calculated above for the case where the union retains an agent and the employer does not. (The payoffs are expressed relative to the case where neither party retains an agent and the payoffs in this latter case are normalized to zero.) The remaining parts of the payoff matrix are easily filled in by the same type of analysis. For simplicity it is assumed that if an employer retains an agent it has the same effect on the distribution of arbitral awards as when the union retains an agent. This makes the payoff matrix symmetric, although it is by no means necessary.

The payoff matrix in Table 1 represents a prisoner's dilemma if $a-x>0$. For in this case it 
pays for the union to retain an agent regardless of what the employer does. If the employer does not retain an agent, the union receives a wage bill increase of $a-x$, which is greater than 0 . (The payoff $a-x$ is called "the temptation" in the extensive literature on the prisoner's dilemma.) Likewise, if the employer does retain an agent, the union is certainly better off doing so also since $-x>-a$. (The quantity $-a$ is called the "sucker's payoff”!) In sum, the union is better off employing an agent regardless of what the employer does.

It is easy to see that when $a-x>0$, precisely the same reasoning applies to the employer's choices. In this case the employer is also better off employing an agent regardless of what the union does. The end result: if the union and the employer do what is in their individual best interests they both retain agents and expend the resources $2 x$, but the arbitration results are precisely the same as what would have occurred if neither union nor employer had retained agents. The private demand for legal services generated in this way is clearly socially inefficient.

It is well known that the existence of a payoff matrix like the one in Table 1 creates incentives for the parties to arrive at cooperative contracts. In particular, if the game is modeled as an infinitely repeated game, the Folk Theorem implies that each of the parties will select the cooperative outcome and not hire agents, as long as the discount rate is high enough.

It is also clear, however, that making such contracts may well be impossible if the parties do not have repeated disputes (or relatively infrequent disputes). Additionally, there are other contexts such as tort litigation where ex ante contracting is impossible. An enormous literature in experimental psychology attempts to clarify the conditions under which cooperation may be expected (for example, see Rapoport 1965 and Axelrod 1984). Suffice it to say here that in the experimental literature the parties do often manage to arrive at the cooperative result. Moreover, 
cooperation tends to increase with experience and with the extent to which the parties appreciate the social dilemma in which they are trapped, while it tends to decrease with the magnitude of "the temptation" to cheat.

It is easy to generalize the payoff matrix and still keep the basic structure of a prisoner's dilemma game. For example, there is no reason why the payoff to retaining an agent must be the same for each party. Suppose that the mean arbitral award is increased by $a$ " when the union alone retains an agent, and that the mean arbitral award is decreased by $a^{\prime}$ when the employer alone retains an agent. The upper right hand corner of the payoff matrix then contains the elements (- $\left.a^{\prime \prime}, a^{\prime \prime}-x\right)$, while the lower left hand corner of the payoff matrix contains the elements $\left(a^{\prime}-x,-a^{\prime}\right)$. These payoffs represent a prisoner's dilemma if $a^{\prime}-x>0$ and $a^{\prime \prime}-x>0$, since in this case "the temptation" to behave noncooperatively exists for both parties. Moreover, the dominant strategies where both parties retain agents is strictly inefficient only if $a^{\prime}-a^{\prime \prime}-x<0$ and $a^{\prime \prime}-a^{\prime}-x<0$.

A similar generalization could be made for costs, with one party facing lower costs than the other. If the employer faces costs $x^{\prime}$ and the union faces costs $x^{\prime \prime}$, then the dominant strategies where both parties retain agents is strictly inefficient only if $a^{\prime}-a^{\prime \prime}-\chi^{\prime}<0$ and $a^{\prime \prime}-a^{\prime}-\chi^{\prime \prime}<0$. The goal in this paper is to estimate the parameters $a^{\prime}$ and $a^{\prime \prime}$ so as to test for the existence of a prisoner's dilemma. As we will document in our empirical analysis for wage disputes in New Jersey, our estimates of $a^{\prime}$ and $a^{\prime \prime}$ are approximately equal to each other. This symmetry in benefits implies that the non-cooperative outcome is suboptimal for both parties, as they both retain agents and spend $x^{\prime}$ and $x^{\prime \prime}$. However, the arbitration results are no different (in expectation) as what would have happened if neither side had hired costly agents.

Note that if there is heterogeneity in costs and benefits for different bargaining pairs (e.g., if one party can hire an agent more cheaply than the other), this could explain why in some cases 
one party hires a lawyer while the other party does not. In cases where it is optimal for one party to hire a lawyer but not the other, there is no prisoner's dilemma. Only bargaining pairs ending up in the non-cooperative outcome represent a prisoner's dilemma.

Another generalization of the payoff matrix would be to let the benefit $a$ or the cost $x$ be random variables. There is likely to be a great deal of uncertainty regarding the lawyer's contribution and to a lesser extent, the lawyer's fees. ${ }^{3}$ In this case, a prisoner's dilemma results if the expected value of the benefit minus the cost of hiring a lawyer is greater than zero, i.e., if $E[a-x]>0$. Uncertainty can help explain why some parties might be observed on the off-diagonal cells of the matrix. In particular, some parties may underestimate or overestimate the benefits to hiring a lawyer, particularly when they have little experience from which to form expectations. Additionally, notice that if employers or unions are risk-averse, they may employ agents even in cases where $a-x$ is negative in expectation. ${ }^{4}$

A final modification of the payoff matrix may be appropriate if the amount of the parties' expenditure on legal resources influences the amount by which the mean of the distribution of arbitral awards is shifted when an agent is retained. For example, suppose that the payoff to the union, in the case where the employer does not retain an agent, increases with additional expenditure on the agent. That is, suppose that $a=a(x)$, with $d a / d x>0$. The union will calculate that the optimal amount to spend on their agent requires that $a(x)-x$ be maximized, which occurs when $d a / d x=1$. As a first approximation, this implies that $d a=d x$, or that the incremental payoff to retaining an agent be equal to the costs of doing so. In this scenario, the improvement in the

\footnotetext{
${ }^{3}$ Uncertainty in fees could arise if lawyers are paid on an hourly basis rather than a fixed fee.

${ }^{4}$ With risk aversion, parties will seek lawyers for even more negative values of $a-x$ as the variance in the non-represented outcome increases. In many instances clients may use lawyers to avoid stepping on the legal land mines they may encounter without professional advice. In final offer arbitration, a system we discuss shortly, the offer of the other side limits just how bad the non-represented case can turn out.
} 
outcome that the parties obtain by retaining an agent is, at the margin, appropriated by the agent. This suggests that an indirect way to measure the fee an agent receives may be available from an analysis of the empirical payoff matrix. In short, $a$ (or $a^{\prime}$ and $a^{\prime \prime}$ ) may well be indirect measures of the magnitude of the agents' fees. ${ }^{5}$

\section{Lawyers and the Arbitration of Wage Disputes}

\section{A. Final Offer Arbitration}

In some cases it may be possible to quantify explicitly the payoffs $a$ and $a-x$ by contrasting the numerical outcomes of a dispute resolution system in each of the four cases indicated by the matrix. In other cases it is only possible to observe who is adjudged the victor in some dispute. This is the situation in final-offer arbitration. In particular, under final-offer arbitration each party submits a proposed wage increase. The arbitrator must select one or the other of these offers without compromise. This is in contrast to conventional arbitration, where the arbitrator often specifies a salary increase between the proposals of the two sides.

In our empirical example, final offer arbitration was the default procedure for resolving disputes in the public sector in New Jersey from 1978 to 1995 . New Jersey law specifies that police and fire department workers, and their municipal employers, enter into arbitration if they can not reach an agreement 60 days before a contract expires. Formal arbitration proceedings involve the choice of an arbitrator, several intermediate hearings where documentation is passed back and forth, and a final hearing where the arbitrator provides the ruling. At each of the points where the parties interact, they can observe whether the other party has retained an expert agent and can respond by hiring an agent for future interactions if it is in their best interest.

\footnotetext{
${ }^{5}$ Another extension would be to allow lawyers to increase the surplus to be split. When there is a single issue under dispute, like a salary increase, a model without this feature seems natural. But in other settings with multiple dimensions over which to bargain, lawyers could increase the surplus.
} 
Since there are often large gaps between such interactions, there is time value to hiring an agent. The proceedings usually span several months and can often take a year or longer. Therefore, it is natural to think the payoff to hiring an agent will increase by every month and for every additional hearing the agent is on the case. We do not observe the timing of when agents are hired, so we will not formally model this time value. However, it plays an important background role in terms of generating a prisoner's dilemma. If there were no time value, then there would be no advantage to hiring an agent first (since the other party would respond by hiring an agent instantaneously), and therefore a prisoner's dilemma could not exist.

\section{B. Estimation Procedure}

A simple model that has been remarkably successful in several final offer applications assumes that the arbitrator first decides what would be a reasonable award, and then selects whichever offer is closest to it (see Farber 1980, Ashenfelter and Bloom 1984, Farber and Bazerman 1986, Ashenfelter, Dow, and Gallagher 1986, and Olson, Dell'Omo and Jarley 1992). If we denote the arbitrator's numerical award by $y$, and the employer and union offers by $m$ and $n$ (where $m<n$ ), the employer's offer is selected if $y-m<n-y$, which is true if $y<(m+n) / 2$. Since $y$ has a normal distribution with mean $u$ and standard deviation $s$, it follows that the probability the employer's offer is selected is $P_{e}=F\{[(m+n) / 2 s]-u / s\}$, where $F\{$.$\} is the value of the cumulative$ unit normal distribution function. $P_{e}=F\{$.$\} is a probit function, with argument (m+n) / 2$, the mean of the employer and union offers. The constant in this probit function, $-u / s$, is the negative of the (standardized) mean of the distribution of arbitrator awards, while the slope, $1 / \mathrm{s}$, is the reciprocal of the standard deviation of this distribution. Graphically, the probability the employer's offer is chosen as a function of the average of the two offers is given by the shaded area in Figure 2.

As described in the previous paragraph, there is a common distribution from which 
arbitrator's decisions are drawn, rather than different distributions for each arbitrator. This modeling choice is motivated by the incentives in many systems which try to make arbitrators impartial and statistically indistinguishable from each other. For example, in our primary example of wage disputes, the arbitrator is chosen with veto input from each of the parties, so that systematically pro-union or pro-employer arbitrators will never hear a case.

With this setup it is a relatively easy matter to determine what the payoff matrix must look like in terms of the underlying probability of an employer victory. In particular, suppose that $p$ represents the value of $P_{e}$ that results when neither union nor employer retain an agent. Then, to first order, the probability that the employer will be victorious (holding constant both the employer and union offers) when only the union retains an agent is $p$-fa/s, where $f$ is the unit normal density function (evaluated at the same point as $p$ ). In effect the mean of the distribution of arbitrator awards is increased by $a$ when the union retains an agent, and this decreases the probability of an employer victory by $f a / s$ (since $-f / s$ is the derivative of $P_{e}$ with respect to $u$ ). Figure 3 illustrates the decrease in the probability of an employer victory when the union hires a lawyer relative to neither side hiring a lawyer. By the same reasoning, when the employer retains an agent, but the union does not, the probability of an employer victory increases by $\mathrm{fa} / \mathrm{s}$. Finally, when both parties retain agents the probability of an employer victory is identical to the case when both parties refrain from engaging agents.

Table 2 contains the payoff matrix translated into the implied probabilities of an employer victory as a function of each of the strategies available to the parties. The symmetry of the payoff matrix translates into symmetry in the probabilities of an employer victory. The most important difference between the payoff matrix and the table of implied probabilities of an employer victory is the absence of any role for the agent's fees in the latter. This is an important 
point, because in some applications it is not possible to measure the payoff matrix directly. A necessary condition for the presence of a prisoner's dilemma payoff structure is that $f a / s>0$, which occurs if $a>0$. This condition will be satisfied if the probability of a union victory, given that the employer does not retain an agent, is greater when the union employs an agent than when it does not. However, finding this to be the case is not sufficient to guarantee that the prisoner's dilemma incentive structure exists. It is also necessary that the union's increased payoff be greater than the cost of obtaining it. That is, we require that $a-x>0$, not just that $a>0$. Unfortunately, it is not possible to determine whether this is the case from an examination of the probability structure alone. In the case of final-offer arbitration there is a fairly natural method for translating from the observed probabilities to the underlying payoff structure, but this need not always be the case.

Asymmetry in the payoff matrix will translate into asymmetry in the probability of an employer victory. If the decrease in the mean of the distribution of arbitral awards is $a^{\prime}$ when the employer retains an agent, the probability of an employer victory when the employer retains an agent and the union does not becomes $p+f a^{\prime} / s$. Similarly, if the increase in the mean of the distribution of arbitral awards is $a^{\prime \prime}$ when the union retains an agent, the probability of an employer victory when the union retains an agent but the employer does not becomes $p-f a " / s$. The probability of an employer victory when both parties retain an agent is thus $p+f\left(a^{\prime}-a^{\prime \prime}\right) / s$. Although the matrix of probabilities no longer retains the symmetric simplicity of Table 2, it is still the case that the probability in the lower right hand cell of the matrix is a simple linear combination of the probabilities in the remaining three cells of the matrix. This is, of course, a restriction that may be tested.

In our main example of arbitrated wage disputes in New Jersey, we will be able to use the 
data to say something about the payoff structure of the prisoner's dilemma game discussed in this section. In particular, we will estimate a model which allows the parties to maximize the expected payoff to hiring an agent. This expected payoff will be a function of both the probability of winning and the wage outcome if they win. In other examples we discuss, it is more difficult to attach a valuation to an employer or union victory. These examples serve as cases which are consistent with a prisoner's dilemma payoff structure, but are less definitive.

\section{Empirical Results}

We collected data on all public sector wage disputes resolved by final-offer arbitration in New Jersey from 1978 to 1995. This period corresponds to the era when final-offer arbitration was the default procedure for the settlement of contract disputes by public safety workers (mainly police officers). ${ }^{6}$ To improve data accuracy, two readers independently entered data for each case docket onto a standard form. Any discrepancies were the rechecked and entered by a third individual. We collected data for 814 cases with available information on lawyer use; 620 of these cases also had information on the employer's and union's final offers.

Simple summary statistics reveal several interesting facts. First, the arbitrators have typically been more likely to select the union's offer than the employer's offer: employers won $39 \%$ of the cases submitted to arbitration during the time period 1978 to 1995 . This result is inconsistent with the notion that the equilibrium outcome in this dispute resolution system is a simple 50\% victory rate for the employer. Moreover, the probability of obtaining these results if $p=.5$ is extremely small. This suggests that either the parties are not behaving symmetrically

\footnotetext{
${ }^{6}$ Richard Lester participated in the design of this arbitration system and followed its development continuously since its founding in 1978. For details see Lester (1989) and Bloom (1980). Starting in 1996, the default procedure switched to conventional arbitration (where the arbitrator is not bound to choose the final offer of one of the parties).
} 
when they submit their final offers, or the arbitrators are not treating the parties' offers symmetrically.

The rate at which employers and unions use lawyers suggests an alternative explanation for these unbalanced win/loss records. Unions are far more likely to enlist the assistance of a professional agent in selecting an arbitrator, preparing the arbitration case, and in presenting this case to the arbitrator. In the period from 1978 to 1995, unions employed lawyers in 83 percent of arbitration cases compared to only 62 percent for employers. If the parties obtain an advantage from retaining an agent, then the fact that the unions are much more likely to retain an agent than are the employers may account for the greater probability that their offer is selected by the arbitrator.

Table 3 provides the empirical analogue to the matrix of predicted probabilities contained in Table 2. This matrix is remarkably similar to the predicted one. The probabilities along the diagonal are nearly equal, and the matrix is fairly close to symmetric. In fact, the advantage to the employer of retaining an agent (an increased win rate of 30 percentage points), is slightly greater than the advantage to the union of retaining an agent (an increased win rate of 22 percentage points). In an additive model this implies that the employer win rate when both parties retain an agent should be $49 \%$, while it is actually only $45 \%$. Despite these small discrepancies, a formal statistical test does not reject the symmetry hypothesis (at the .05 confidence level).

Although the results in Table 3 are suggestive, they suffer from two deficiencies. First, they do not control for the offers the parties have made. If these offers are correlated with the probability that the parties retain an agent, then the results in Table 3 may simply reflect the possibility that the parties who retain agents make less aggressive offers than those who don't. 
Second, the probability matrix in Table 3 does not allow comparison of the financial payoffs associated with retaining an agent against the costs.

Table 4 remedies these problems. It contains the results of fitting a probit function to the actual arbitrator selections. The probit function contains the mean of the parties' final offers (which are expressed as percent increases in wages), year dummies, and dummy variables indicating whether the union or employer retained a lawyer. ${ }^{7}$ The probit estimates reveal that hiring a lawyer increases the chance of a party winning by about 25\% for both the employer and the union. The coefficients on the lawyer dummy variables can be translated into estimates of the shifts in the distribution of arbitral awards that result from retaining an agent. The estimated shifts control for the offers made by the parties and indicate that when the union retains an agent the distribution of awards is shifted upward by $2.12 \%$. Likewise, the results indicate that when the employer retains an agent the distribution of awards is shifted downward by $2.48 \%$. These shifts are statistically significant (at the .05 significance level) and represent a change of about two-thirds of a standard deviation of the arbitrator's preferred distribution of awards.

The empirical results in Table 4 imply that $a>0$, and that each party increases the chance their offer will be accepted when they retain agents. There still remains the question of whether the benefits are worth the cost, however. It seems very likely that they are. A permanent increase in the compensation of a police officer by $1 \%$ would have a discounted present value of perhaps $\$ 2,000$ to $\$ 3,000$. Legal fees are typically said to be about $\$ 5,000$ per case for the union, and up to $\$ 15,000$ per case for the employer (see Lester 1989). It would take a bargaining unit of only 5 to 10 employees to make it well worth the cost for each party individually to retain an agent. In short, it appears that the incentive structure in New Jersey's final-offer arbitration

\footnotetext{
${ }^{7}$ There are fewer observations in Table 4 compared to Table 3, since information on the final offers of the parties is not available for all cases.
} 
system creates a prisoner's dilemma.

A potential limitation with the analysis is the possibility that some omitted variable is influencing the outcomes, and that it is correlated with whether the parties retain an agent. In this case the estimated differential payoffs to retaining an agent may be systematically biased. ${ }^{8}$ Apart from implementing a field experiment with randomized trials, however, this type of omitted variable bias is a potential problem for all empirical studies. While our results should be interpreted with this caution in mind, at a minimum, tests of the prisoner's dilemma incentive structures set out here should be used to investigate other dispute resolution systems, including the court system.

Although possible endogeneity cannot be addressed with our available data, a few field studies that have controlled for the presence of counsel through randomization tend to find a positive effect of having counsel. Greiner and Pattanayak (2012) found a modest improvement in the outcome of appeals to state administrative law judges based on a randomized offer of counsel. Stapleton and Teitelbaum (1972) found a statistically significant benefit in terms of delinquency findings for juveniles offered lawyers. Seron et al. (2001) found that tenants offered lawyers suffered significantly fewer adverse outcomes than tenants not offered lawyers.

There are several questions raised by our findings for final offer arbitration in New Jersey, including why the unrepresented parties don't retain lawyers and whether the parties can sustain cooperative behavior over time. These, of course, are precisely the puzzles raised in the extensive empirical literature about the prisoner's dilemma based on experimental games. Before

\footnotetext{
${ }^{8}$ For example, suppose lawyers refuse to represent employers or unions with weak cases. Then the use of lawyers might be correlated with higher success rates, even though the driving factor is the strength of the case. In discharge grievances, custody battles, and other types of disputes where details of the case are largely based on what occurred in the past, lawyer screening of clients is more likely to be an important issue. In disputes over wages or benefits, however, the lawyer can always change the strength of the case by convincing his client to make a more reasonable final offer.
} 
exploring these important questions with our New Jersey data, we first present evidence on the incentives to retain agents in other systems in the following section.

\section{Incentives to Retain Agents in other Systems}

\section{A. Discharge Grievances}

Union contracts commonly specify that if an employee is unfairly treated, he or she may formally object to the treatment. The employee does this by filing a grievance. If the grievance cannot be settled through negotiation, then it is usually presented to an arbitrator for decision.

Grievances may be filed for many different reasons, but a common case is one where an employee has been discharged for some behavior that is unacceptable to the employer. Block and Stieber (1987) have reported a very thorough study of a sample of discharge grievances, which includes arbitrator decisions that are both published and unpublished. In their study Block and Stieber estimated the probability that a discharge grievance would be denied (the union loses) as a function of whether the parties did or did not retain attorneys to assist in the selection of the arbitrator, and in the preparation and presentation of their case to the arbitrator. The results of their study are contained in the probability matrix in Table $5 .^{9}$

The results in Table 5 are similar to those in Table 3, and they are consistent with the prisoner's dilemma incentive structure of Table 2. As before, arbitrator decisions favor unions in more than $50 \%$ of disputes, even when both parties retain lawyers. Like the New Jersey finaloffer arbitration cases, the probability matrix here is somewhat asymmetric, but here the asymmetry indicates that the probability of a union victory is changed by more when the union retains a lawyer than when the employer retains a lawyer.

One unusual feature of the Block and Stieber study is the presence in the data of many

\footnotetext{
${ }^{9}$ An additional example using discharge grievances can be found in Wagar (1994).
} 
disputes decided by the same arbitrator. The results in Table 5 control (through the introduction of arbitrator dummy variables) for the arbitrator in the case. As a result, Table 5 implies that the effectiveness of lawyers in changing outcomes is not due primarily to their ability in helping the parties to select arbitrators that will be more favorably disposed toward their cases.

It is not possible to convert the probabilities in Table 5 into a payoff matrix of the form in Table 1 because it is difficult to attach a valuation to a union or employer victory. Presumably, the union worker's loss is the discounted present value of the difference between his or her wage in the unionized job and his or her wage elsewhere. Union wage premiums are generally estimated to be around $10 \%$, so a job that would otherwise pay $\$ 25,000$ may generate a premium of $\$ 2,500$ per year, or a discounted present value of perhaps $\$ 25,000$. Since the union increases its victory rate by 18 percentage points by hiring a lawyer, the legal fee for a discharge case could approach $\$ 5,000$ before the payoff would no longer make it worthwhile for the union to retain a lawyer. Precisely how to value the employer's victory in such a case is an open question.

In sum, the data from the grievance arbitration cases suggests the effect of retaining legal representation on the probability of each party being victorious is substantial. Reasonable calculations suggest it is quite possible that the incentive structure in the grievance arbitration system represents a prisoner's dilemma.

\section{B. Arbitration of Court Claims}

For a variety of reasons several courts have adopted a procedure whereby the parties in a civil lawsuit submit their claims to arbitration. Adler, Hensler, and Nelson (1983) examine the outcomes of such an arbitration system which has been operating in Pittsburgh for over thirty years. In their study, Adler, Hensler, and Nelson estimate the percentage of a plaintiff's claim that is awarded to the plaintiff as a function of whether the parties retain a lawyer. The results of 
this study are contained in the estimated payoff matrix in Table 6. These data have very similar implications to those contained in Tables 3 and 5. Again, the payoff matrix is only approximately symmetric. Here the advantage to using a lawyer is greater for the defendant than the plaintiff.

An especially useful feature of the data in Table 6 is that they are a very natural representation for the payoff matrix. Suppose, for example, the plaintiff's attorney is paid on the traditional contingent fee basis. In this form of payment the plaintiff's fee is established as onethird of the award, if any. According to Table 6, a plaintiff who retains a lawyer may expect to obtain $82 \%$ of his or her claim if the defendant does not use a lawyer. Such a plaintiff must expect to pay about $27 \%$ of the claim to the lawyer, however. On the other hand, the expected advantage to the plaintiff of retaining a lawyer is $22 \%(82 \%-60 \%)$ of the claim. The result: The advantage to the plaintiff is just about equal to the cost.

The payoff matrix in Table 6 also demonstrates the real costs of legal representation. Suppose that the plaintiff pays his or her attorney in accord with the contingent fee system. If the plaintiff retains an attorney and the defendant does not, then the plaintiff expects to have a net payoff of 55\% (82\%-27\%) of the claim. This is slightly below the $60 \%$ of the claim that the plaintiff may expect if the defendant does not retain a lawyer. On the other hand, if the plaintiff and the defendant both retain attorneys, then the plaintiff may expect to receive only $43 \%$ (65\%$22 \%$ ) of the claim. Nevertheless, if the plaintiff does not retain an attorney, he or she may well be stuck with the "sucker's payoff” of only $24 \%$ of the claim.

After a careful study of lawyer’s costs, Adler, Hensler, and Nelson conclude that, “...taking into account the amount they spend on legal fees, represented litigants can expect to obtain better net outcomes, on average, than litigants who appear pro se” (that is, unrepresented 
by lawyers). ${ }^{10}$ This, of course, is precisely what we should expect if the incentive structure in the Pittsburgh arbitration system represents a prisoner's dilemma.

\section{Child Custody Disputes}

Among the most difficult disputes to study are those that arise from the breakup of the family. Among other problems, monetary valuations of the various outcomes of the dispute are difficult, if not impossible, to establish by an outside observer. One of the most contentious issues in such disputes is the question of who will retain physical custody of the child of two divorced parents. In an empirical study, Mnookin, Maccoby, Depner, and Albiston (1989) have presented some data on the outcomes of such disputes as a function of whether the mother and father retain lawyers. These data are arrayed in the probability matrix in Table 7.

The results in Table 7 have very similar implications to those in the previous tables. The likelihood that a mother or father prevails in retaining the physical custody of the child is clearly related to whether they retain a lawyer. Although the probability matrix is asymmetric, it is consistent with an additive structure for the payoff matrix. For example, under an additive structure the predicted percentage of cases where the mother retains custody of the child when both parents retain lawyers is $69 \%$. This may be contrasted against the $65 \%$ of cases where the mother actually retained custody in these circumstances.

There are many potential problems in using the results of Table 7 to make inferences. For example, Mnookin, et. al. report that in virtually every case the mother wished to have physical custody of the child. However, it is not clear that fathers are so interested in this matter.

\footnotetext{
${ }^{10}$ Adler, Hensler, and Nelson do not consider the possibility that this may lead to a prisoner's dilemma incentive structure, and their analysis of net costs takes into account the actual empirical frequency of the other parties use of legal representation. As a result, instead of a study of the payoff matrix, they are reporting estimates of the net payoffs actually received by the parties.
} 
Thus, it is possible that whether the father retains a lawyer is simply a signal that the father wishes to obtain custody of the child. If this is the case, then Table 7 may overstate the impact on the outcomes when the father retains a lawyer as compared to the case when the father does not retain a lawyer. A more complete statistical analysis is required before these results should be accepted at face value. Despite these reservations, it is seems possible that the court system for dealing with marital disputes over child custody may also contain the incentive structure of a prisoner's dilemma.

\section{The Evolution of Lawyer Use}

\section{A. Learning over Time}

One of the more interesting features of the New Jersey arbitration dataset analyzed in Section III is that it spans the entire period during which final offer arbitration was used, from 1978 to 1995 . We can therefore study the system from its very beginnings, including the evolution of lawyer use and how unions and employers learned about the system over time. When final-offer arbitration began in New Jersey, employers and unions arguably had little information about arbitrators' beliefs and the effect of hiring agents.

Lawyer use by the parties starts out low, but increases over time. In 1978, the first year of arbitration in New Jersey for police and fire employees, both sides use lawyers in only 30 percent of arbitration cases. Indeed, for the first third of our sample period (1978-1983), both sides use lawyers $44 \%$ of the time. This rises to $51 \%$ for the middle third of our sample (19841989) and shoots up further to $67 \%$ of cases where both sides use a lawyer in the last third of our sample (1990-1995). Using a chi-square test, this increase over time is highly statistically significant $($ chi-square statistic $=27.0, \mathrm{p}$-value $=0.001)$.

Figure 4 plots the pattern of agent usage by employers and unions over time. As can be 
seen in the figure, this initially low fraction is largely due to low lawyer usage by employers. By the end of our sample period, agent use is the dominant choice for both parties, with lawyer usage rates for the employer and union reaching roughly 90 percent. As the figure illustrates, the lopsided use of lawyers by the union compared to the employer declines substantially over time.

As documented in Table 8, this time series pattern of lawyer use by the parties predicts the time series pattern in arbitration outcomes. Regressing the employer victory rate in a year on the difference in lawyer usage rates (the fraction of cases the employer uses a lawyer minus the fraction of cases the union uses a lawyer) yields a coefficient estimate of 0.47 (s.e. $=0.16$ ). In other words, a 10 percentage point increase in the use of lawyers by employers compared to unions is associated with a 4.7 percentage point increase in employer victories.

There is some suggestive evidence that previous experience with arbitration affects future lawyer use, especially for employers. As depicted in Figure 5, employers in bargaining units that have never been involved in arbitration before hire lawyers $57 \%$ of the time. This percentage rises to $62 \%$ the second through fourth time an employer is involved in an arbitrated dispute, and continues to rise to $68 \%$ for the fifth or higher arbitrated dispute. The increase for unions is much smaller, although they also start out using lawyers at a higher rate. Using a chi-square test, the difference in lawyer use based on past arbitration experience is significant for employers at the $10 \%$ level (chi-square statistic $=5.1$, p-value $=0.08)$ and insignificant for unions (chi-square statistic $=1.4$, p-value $=0.49$.

One explanation for the pattern of agent use in Figures 4 and 5 is that some parties (particularly employers) learned about the dangers of not hiring a lawyer gradually over time. Alternatively, employers may have behaved more cooperatively in the (unfulfilled) hope that this would encourage a union response. In either case, it appears the parties have converged to the 
non-cooperative equilibrium by the end of our sample period, with most parties hiring lawyers.

There still remains the question of why the remaining unrepresented parties at the end of our sample period do not hire lawyers. One possibility is that costs vary, so it makes sense for some units to hire lawyers but not others, even after the parties understand how things work. For example, it is more expensive (on a per employee basis) for a small union to hire a lawyer compared to a large union. If costs vary in this way, some parties will face prisoner's dilemma incentives while others will not.

\section{B. Lawyers as Moderators of Client Bias}

The empirical analysis in Section III provides convincing evidence that, left alone, the parties do not construct and present their offers as successfully as when they retain expert agents to assist them. So far we have modeled lawyers as helping the parties by moving the arbitrator to favor their position independent of the facts. In principle, however, lawyers could also help to eliminate inefficiencies in the conduct of strategic interaction. In this section, we extend the model to allow lawyers to improve the process by moderating any biases or overconfidence that may have led to impasse in the first instance.

To motivate the analysis it is useful to first ask why the parties to a dispute end up in arbitration in the first place. Since arbitration is costly in terms of money, time, and labormanagement relations, it would seem to be in the best interests of both parties to agree to a settlement. One leading explanation for bargaining impasse is that the parties have divergent and overly optimistic expectations about the arbitrated outcome. ${ }^{11}$ With such biases, negotiations are

\footnotetext{
${ }^{11}$ Asymmetric information or differing levels of optimism have been used to explain why ex-post negotiations sometimes fail (Bebchuck 1984, Priest and Klein 1984) and to describe attorney fees in contingent cases (Dana and Spier 1993). Other examples include Babcock et al (1995), Babcock and Olson (1992), Bolton and Croson (2012), Farber and Bazerman (1989), Farber and Katz (1979), Guthrie and Sally (2004), and Hovander (2010).
} 
more likely to fail and the parties will be forced into arbitration. One useful contribution of lawyers may be that they moderate the unrealistic expectations of their clients. To make this analysis concrete, suppose the two parties have divergent beliefs about the mean of the arbitrator's preferred award distribution. If lawyers help their clients understand what is reasonable in a given case, there are now two potential advantages to hiring them. As before, lawyers shift the distribution of the arbitrator's preferred award (as depicted in Figure 1), but now they also provide clients with potentially more accurate (i.e., less biased) information about the location of the arbitrator's award distribution.

In the absence of lawyers, the party with less bias will win more often, since their wage offer will be closer to the arbitrator's preferred award on average. Moreover, lawyers have the potential to moderate final offers, and hence increase the probability their client will win the case. It is possible to test whether lawyers moderate biased expectations by looking at the final offers of the parties. This is a particularly important characteristic of the final-offer system, since the offers of the parties provide a complete summary of their strategic behavior. Moreover, it is possible to estimate the moderating effect of lawyers even if the center of the arbitral distribution is not known by using a fixed-effects estimator, much in the manner of the fixedeffects estimator so often used to eliminate bias in the typical cross-section relationship. Subtracting the final offer of the employer from the final offer of the union differences out any common observed or unobserved variables.

Figure 6 graphs the average spread between the union's and the employer's final offers for each year. In the first six years of our data this difference varies between two and three percentage points, but by 1984 it drops to 1.5 percentage points. The decreasing trend in final offers roughly parallels the increasing use of agents over time plotted in Figure 4, suggesting that 
agents may moderate final offers. ${ }^{12}$ To determine if this drop is driven by the use of lawyers, in Table 9 we regress the difference between the final offers of the union and employer on dummy variables for whether the employer hires an agent and whether the union hires an agent, where to capture differences over time, we interact these lawyer use dummies with three time period dummies.

The coefficient for employer's agent usage is significantly negative for the first time period of 1978-1983. The estimate implies that lawyers cause employers to increase their offers by over half of a percentage point on average during 1978-1983. This is precisely the direction that the moderating effect would be expected to be for an employer. However, we do not find any effects for later time periods, when the estimated coefficients are close to zero and statistically insignificant. So while lawyers may have helped to moderate employer expectations in the nascent years of New Jersey's final offer arbitration system, lawyers no longer served this important function later on. In addition, none of the coefficients for the union are statistically significant, suggesting that any overconfidence or biases may have been asymmetric.

\section{Conclusion}

The analysis in this paper spells out how the demand for legal services may arise from a set of incentives like those contained in the classical prisoner's dilemma game. When incentives are so structured it is in each individual's interest to behave in a way that makes the parties jointly worse off. Although there are obvious incentives for the parties to reach enforceable contracts when the incentives are like those in a prisoner's dilemma, it is far from clear that it is possible to implement such contracts.

\footnotetext{
${ }^{12}$ The wide gap in offers in the early years may also reflect learning by the parties about how arbitrators treat more extreme final offers (i.e., learning about the arbitrators' preferred award distribution).
} 
All of the data available on differential outcomes in the dispute resolution systems studied here are consistent with the incentives present in a prisoner's dilemma. In short, the data imply that it is individually rational for the parties to retain costly agents so as to increase the likelihood that they will prevail, even though there is little evidence that the result will be any different from what would occur if both parties did not retain agents.

A key issue in the empirical analysis of strategic behavior is whether expert agents have efficiency-enhancing effects. Other researchers have argued that lawyers can help bridge costly impasse by encouraging cooperation rather than conflict in disputes (see Gilson and Mnookin, 1994, Mnookin 2010). The unique institutional structure we study, and the longitudinal character of the data we use, provide a unique opportunity to study this question. We find some evidence that expert agents may have played an important role in moderating biases early in the history of the system. However, the parties have slowly evolved to a non-cooperative equilibrium where the use of third-party agents has become nearly universal and where agents are used primarily to move the arbitrator's decisions.

If these empirical results do accurately portray the incentive structures the parties face in most dispute resolution systems, they raise three important questions. First, do the parties respond to these incentives and employ an excess amount of legal services? None of the empirical material in this paper directly addresses this issue. The experimental psychology literature indicates that the mere presence of a prisoner's dilemma incentive structure does not automatically lead to noncooperative behavior, even in situations where it would be most expected. (Indeed, this is often considered a major deficiency in the usefulness of game theoretic solutions as positive predictions about behavior. Game theoretic solutions strongly predict that noncooperative behavior should be the result in a prisoner's dilemma game. See Luce and Raiffa 
(1957).) It is likely that behavior in ongoing dispute resolution systems parallels the experimental behavior to some extent. For example, some union-employer contracts specify “expedited arbitration” for certain grievances. Expedited arbitration usually prohibits the use of lawyers by the parties, and specifies that the arbitrator's decision in such cases will have no value in setting "a precedent.” Apparently some bargaining pairs are able to cooperate in the presence of a prisoner's dilemma payoff structure, while others are not. It would be interesting to know just how common such cooperation actually is. It seems likely that cooperative behavior will be easier to encourage when it is possible to alter the temptation to cheat and when the parties are aware of the social dilemma they face.

Second, it is natural to ask just what mechanism it is that produces the prisoner's dilemma incentive structures in dispute resolution systems. It may be that lawyers help convince arbitrators or judges to rule in favor of their clients with a more professional and persuasive presentation of the case. If so, both parties will face strong incentives to retain costly lawyers. Lawyers may also offer clients the benefit of past experience gained from similar arbitration or court cases. For example, the lawyer's expertise may be used to select the third-party decisionmaker in a dispute resolution system. In the courts the lawyer will help the client to "shop for the most favorable judge" or to "select the favorable jury." Or perhaps lawyers are skilled at uncovering facts which bolster their client's argument. In both of these cases the lawyer must expend resources to research and accumulate useful information. Of course, if the other party engages in the same behavior then the mean result will be unchanged, and both parties will have paid a lawyer's fee without any corresponding gain in the mean result. On the other hand, it is likely that the variance in the outcomes of the dispute resolution process will be reduced if both parties engage in this behavior, and this may be an unintended benefit to the process. Of course 
this leaves open the question of whether the introduction of extra information into arbitration proceedings or judge, jury, and arbitrator shopping has benefits great enough to justify the social costs.

Finally, the empirical results in this paper raise questions about the efficiency of AngloAmerican legal procedures that are provocative and apparently very controversial. Gordon Tullock (1980) has argued for the superiority of continental (or “inquisitorial”) trials over AngloAmerican (or "adversarial”) trials primarily on the grounds that the adversarial system sets up prisoner's dilemma incentives that lead to over-investment in legal resources. Despite some arguments to the contrary, ${ }^{13}$ most of the empirical issues raised by Tullock are rarely addressed by legal scholars. As Tullock observes, lawyers are not generally encouraged to acknowledge this problem or to study it, perhaps because it is not in the best financial interests of the legal profession. ${ }^{14}$ The fact that the legal profession has a vested interest in the legal system, however, raises questions about the role of institutional structures in the law and the motivation for their existence. While not all lawyering is likely to be prisoner's dilemma material, it would be interesting to consider whether some of the existing rules of legal procedure act to enforce the prisoner's dilemma incentive structure and thereby increase the demand for legal services.

\footnotetext{
${ }^{13}$ See especially Landes and Posner (1979). A more general theoretical discussion of some related issues is contained in Jack Hirshleifer (1987).

${ }^{14}$ Tullock (1980, p. 97), despite acknowledging that he is a lawyer, is more blunt: “A change from our system to the continental system would eliminate a sizable part of the demand for lawyers A sharp fall in the demand for lawyers would, of course, impoverish the present profession. Many lawyers would become vacuum-cleaner salesmen, law schools would be compelled to close... Under the circumstances, the opposition of the lawyers to the type of legal system used on the continent is understandable."
} 


\section{REFERENCES}

Adler, Jane, Deborah Hensler and Charles Nelson. 1983. Simple Justice: How Litigants Fare in the Pittsburgh Court Arbitration Program. Institute for Civil Justice, Rand Corporation.

Ashenfelter, Orley. 1987. Arbitrator Behavior. American Economic Review, 77:342-346.

Ashenfelter, Orley and David Bloom. 1984. Models of Arbitrator Behavior: Theory and Evidence. American Economic Review, 74:111-125.

Ashenfelter, Orley and Gordon B. Dahl. 2012. Bargaining and the Role of Expert Agents: An Empirical Study of Final Offer Arbitration. Review of Economics and Statistics, 94:116132.

Ashenfelter, Orley, James Dow and David Gallagher. 1986. Arbitrator and Negotiator Behavior Under an Appellate System. Mimeo, Industrial Relations Section, Princeton University.

Ashenfelter, Orley Janet Currie, Henry Farber and Matthew Spiegel. 1992. An Experimental Comparison of Dispute Rates in Alternative Arbitration Systems. Econometrica, 60:1407-1433.

Axelrod, Robert. 1984. The Evolution of Cooperation. New York: Basic Books.

Babcock, Linda, George Loewenstein, Samuel Issacharoff and Colin Camerer. 1995. "Biased Judgments of Fairness in Bargaining,” American Economic Review, Vol. 85, No. 5, pp. 1337-1343.

Babcock, Linda and Craig Olson. 1992. "The Causes of Impasses in Labor Disputes,” Industrial Relations, Vol. 31, No. 2, pp. 348-360.

Bebchuk, Lucian A. 1984. Litigation and Settlement under Imperfect Information. Rand Journal of Economics, 15:404-415.

Block, Richard and Stieber, Jack. 1987. The Impact of Attorneys and Arbitrators on Arbitration Awards. Industrial and Labor Relations Review, 40:543-555.

Bloom, David. 1980. Customized 'Final-Offer': New Jersey’s Arbitration Law. Monthly Labor Review, 103:30-33.

Bloom, David. 1986. Empirical Models of Arbitrator Behavior under Conventional Arbitration. Review of Economics and Statistics, 68:578-585.

Bolton, Gary and Rachel Croson. 2012. The Oxford Handbook of Economic Conflict Resolution. Oxford University Press.

Dana, James, Jr. and Kathryn Spier. 1993. Expertise and Contingent Fees: The Role of 
Asymmetric Information in Attorney Compensation. Journal of Law, Economics and Organization, 9:349-367.

Farber, Henry. 1980. An Analysis of Final-Offer Arbitration. Journal of Conflict Resolution, 5:683-705.

Farber, Henry and Bazerman, Max. 1986. The General Basis of Arbitrator Behavior: An Empirical Analysis of Conventional and Final-Offer Arbitration. Econometrica, 54:1503-1528.

Farber, Henry and Max Bazerman. 1989. "Divergent Expectations as a Cause of Disagreement in Bargaining: Evidence from a Comparison of Arbitration Schemes," Quarterly Journal of Economics, Vol. 104, pp. 99-120.

Farber, Henry and Harry Katz. 1979. "Arbitration and the Incentive to Bargain,” Industrial and Labor Relations Review, Vol. 33, No. 1, pp. 55-63.

Gilson, Ronald and Robert Mnookin. 1994. "Disputing through Agents: Cooperation and Conflict between Lawyers in Litigation,” Vol. 94, No. 2, pp. 509-566.

Greiner, James and Cassandra W. Pattanayak. 2012. Randomized Evaluation of Legal Assistance: What Difference Does Representation (Offer and Actual Use) Make? The Yale Law Journal 121:2118-2214.

Guthrie, Chris and David Sally. 2004. Impact Bias: The Impact of the Impact Bias on Negotiation. Marquette Law Review 87:817-828.

Hirshleifer, Jack. 1987. The Economic Approach to Conflict. In Gerard Radnitzky and Peter Bernholz, eds. Economic Imperialism: The Economic Approach Applied Outside the Field of Economics. Paragon House Publishers.

Hovander, Elisa. 2010. Optimistic Biases: Implications for Incentives and Dispute in Contractual Relationships. Working paper.

Katz, Avery. 1988. Judicial Decisionmaking and Litigation Expenditure. International Review of Law and Economics, 8:127-143.

Kerkmeester, Heico. 1995. Game Theory as a Method in Law and Economics. In Boudewijn Bouckaert and Gerrit De Geest, eds. Essays in Law and Economics II: Contract Law, Regulation, and Reflections on Law and Economics. Antwerpen, Maklu.

Kritikos, Alexander. 2006. The Impact of Compulsory Arbitration on Bargaining Behavior: An Experimental Study. Economics of Governance. 7:293-315.

Landes, William and Richard Posner. 1979. Adjudication as a Private Good. Journal of Legal Studies, 8:235-284. 
Lester, Richard. 1989. Analysis of Experience Under New Jersey's Flexible Arbitration System. The Arbitration Journal, 44:14-21.

Luce, R. Duncan and Raiffa, Howard. 1957. Games and Decisions. John Wiley \& Sons.

Mnookin, Robert. 2010. Bargaining with the Devil. Simon \& Schuster.

Mnookin, Robert, Eleanor Maccoby, Catherine Albiston and Charlene Depner. 1990. Private Ordering Revisited: What Custodial Arrangements are Parents Negotiating? In Stephen Sugarman and Herma Hill Kay, eds. Divorce at the Crossroads. Yale University Press.

Olson, Craig, Gregory Dell'Omo and Paul Jarley. 1992. A Comparison of Interest Arbitrator Decision-Making in Experimental and Field Settings. Industrial and Labor Relations Review, 45:711-723.

Plott, Charles and Peter Coughlan. 1997. An Experimental Analysis of the Structure of Legal Fees: American Rule vs. English Rule. Working paper \#1025, California Institute of Technology.

P’ng, Ivan Paak-Liang. 1983. Strategic Behavior in Suit, Settlement, and Trial. Bell Journal of Economics, 14:539-550.

Priest, George and Benjamin Klein. 1984. The Selection of Disputes for Litigation. Journal of Legal Studies, 13:1-55.

Rapoport, Anatol and Chammah, Albert. 1965. Prisoner's Dilemma: A Study in Conflict and Cooperation. The University of Michigan Press.

Reinganum, Jennifer and Louis Wilde. 1986. Settlement, Litigation, and the Allocation of Litigation Costs. Rand Journal of Economics, 17:557-566.

Seron, Carroll et al. 2001. The Impact of Legal Counsel on Outcomes for Poor Tenants in New York City’s Housing Court: Results of a Randomized Experiment. Law and Society Review, 35:419-434.

Spier, Kathryn. 1994. Settlement Bargaining and the Design of Damage Awards. Journal of Law, Economics and Organization, 10:84-95.

Stapleton, W. Vaughan and Lee E. Teitelbaum. 1972. In Defense of Youth: A Study of the Role of Counsel in American Juvenile Courts. Russell Sage Foundation.

Tullock, Gordon. 1980. Trials on Trial. Columbia University Press.

Wagar, Terry. 1994. The Effect of Lawyers on On-Discipline/Discharge Arbitration Decisions. Journal of Labor Research. 94:283-300. 


\section{Table 1}

\section{Proportionate Effects on the Net Wage Bill and Net Value Added of Union and Employer Strategies to Use a Lawyer}

\section{Union Uses:}

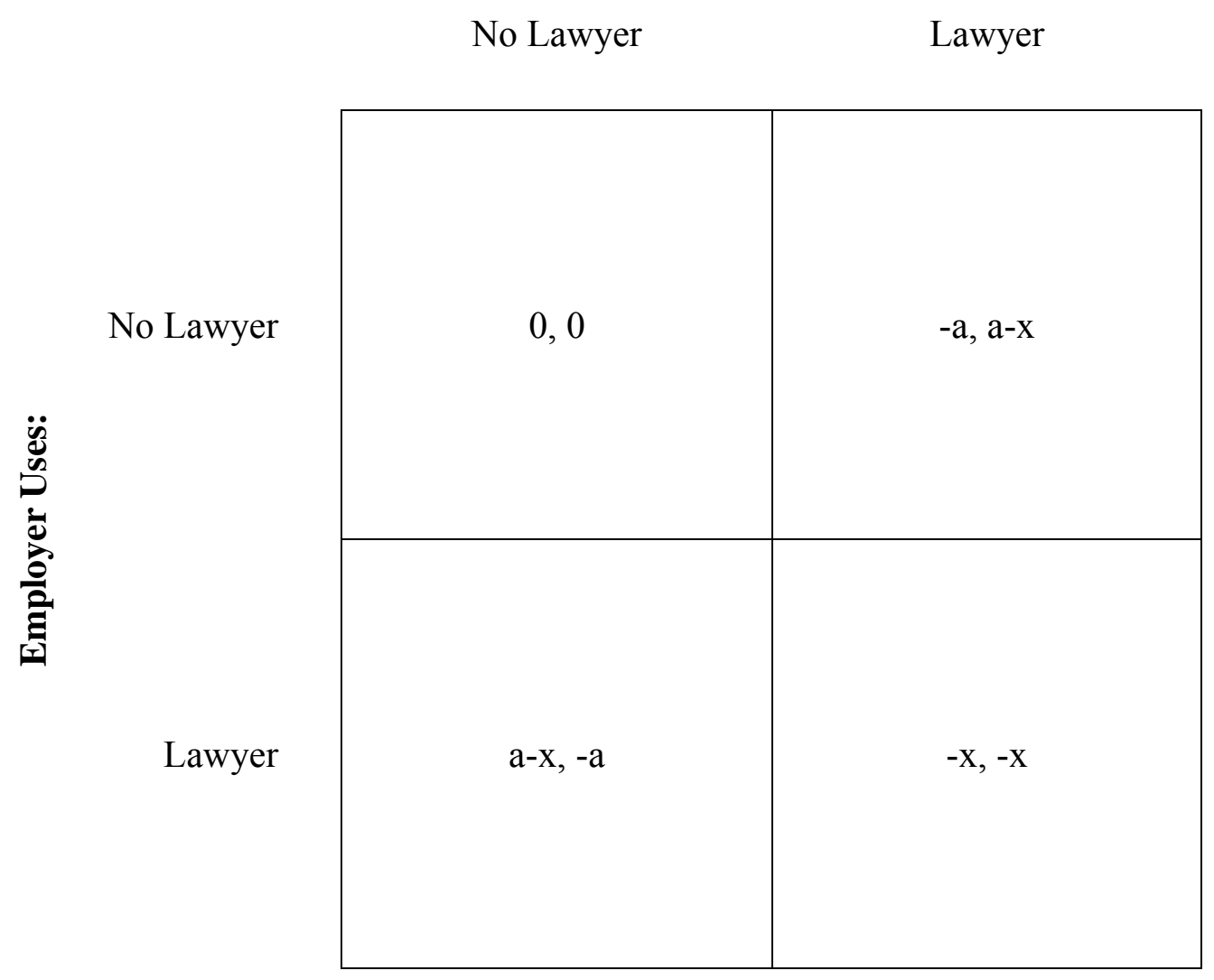

Note: The first entry represents the employer's payoff and the second entry represents the union's payoff.

$\mathrm{a}=$ mean shift in the distribution of arbitrator awards resulting from the use of a lawyer $\mathrm{x}=\operatorname{cost}($ as a percentage of the wage bill) of using a lawyer 


\section{Table 2}

\section{Predicted Effects on the Percentage of Employer Victories in Final-Offer}

Arbitration of Union and Employer Strategies to Use a Lawyer

\section{Union Uses:}

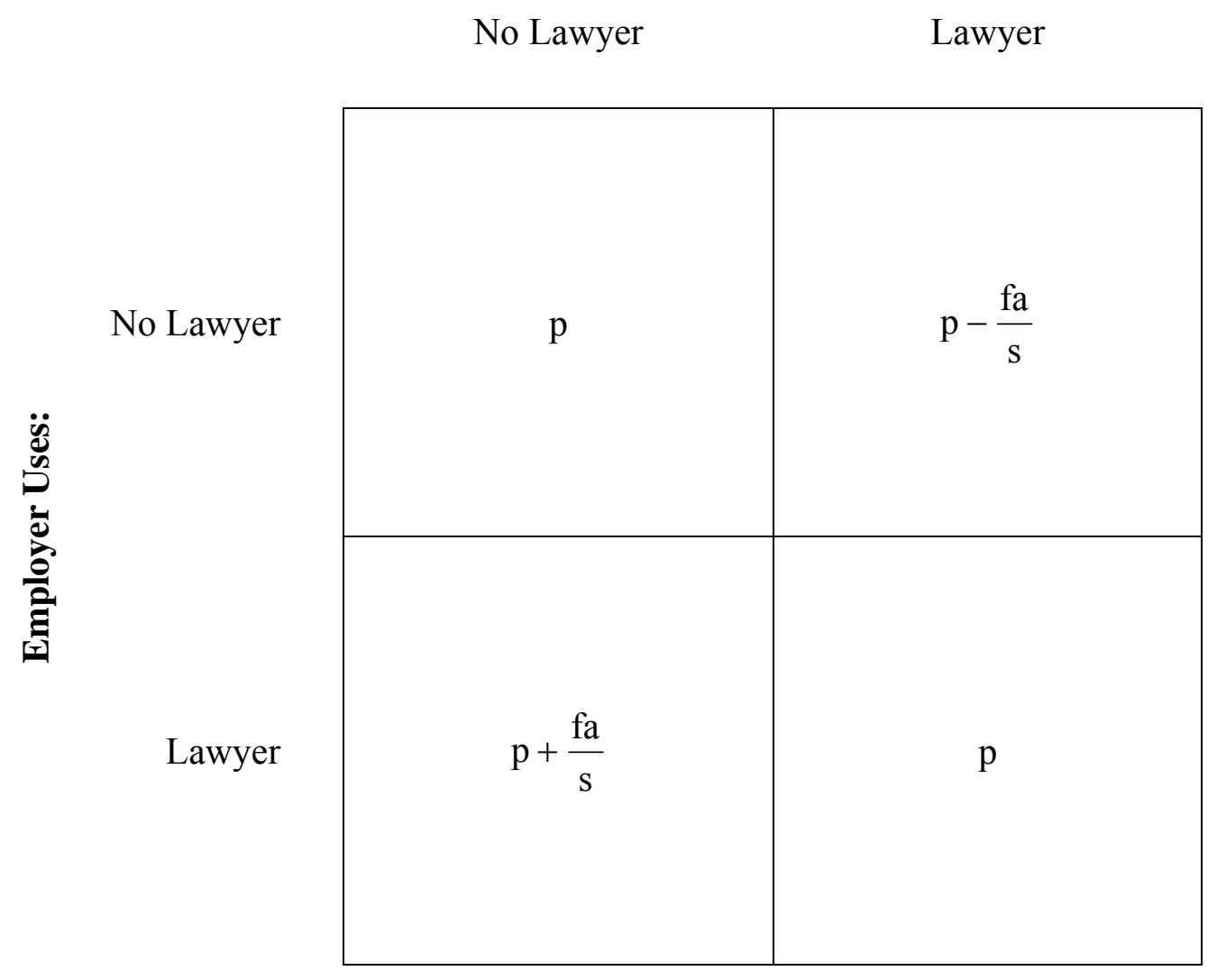

$\mathrm{f}=$ normal density

$\mathrm{a}=$ mean shift in the distribution of arbitrator awards resulting from the use of a lawyer

$\mathrm{s}=$ standard deviation of arbitrator awards 


\section{Table 3}

Employer Victories in Final Offer Arbitration in New Jersey, 1978-1995

\section{Union Uses:}

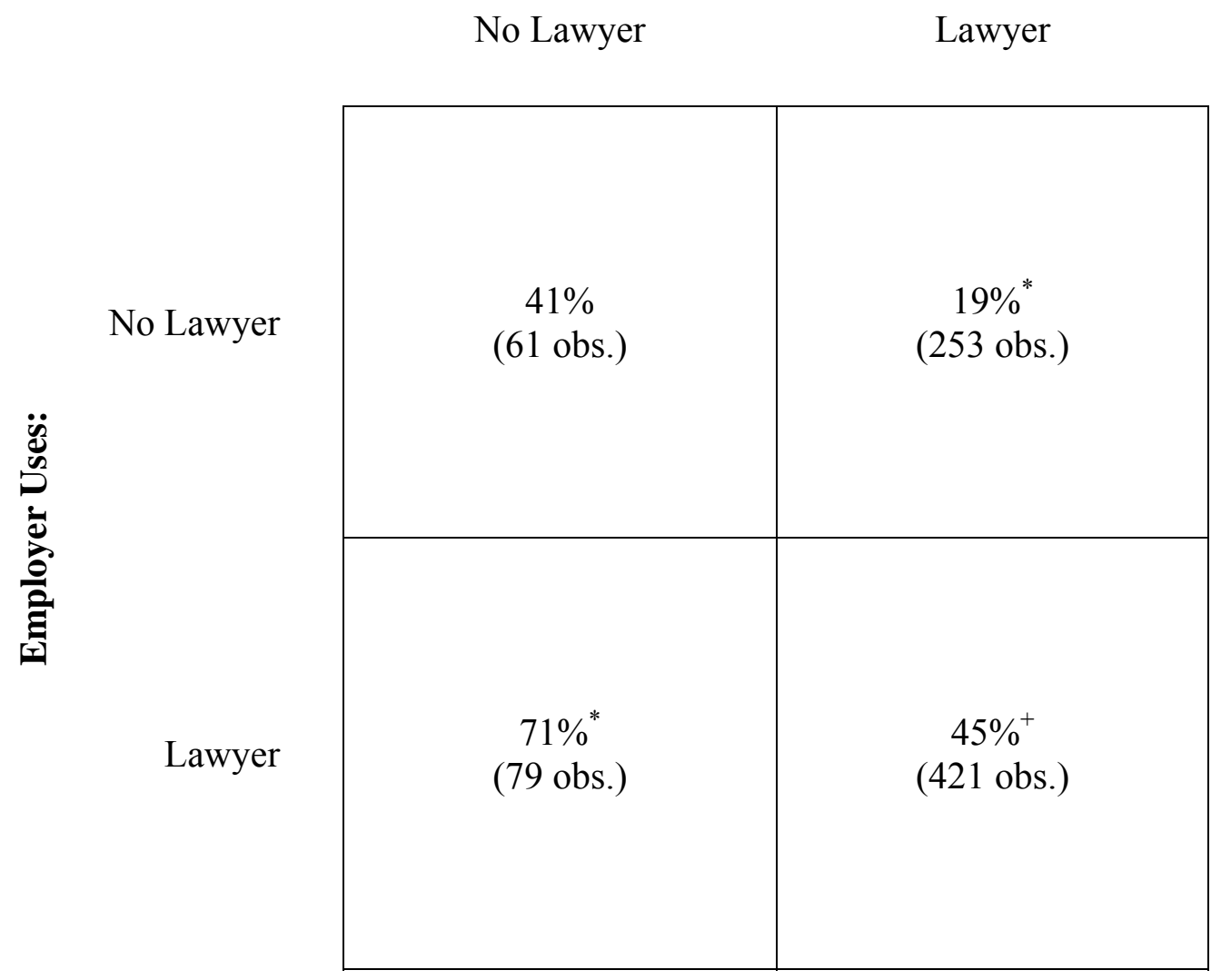

Note: 814 Observations.

*Award rate is significantly different from the rate when neither party uses a lawyer (at the .05 significance level)

${ }^{+}$Award rate is not significantly different from the rate when neither party uses a lawyer (at the .05 significance level) 


\section{Table 4}

Estimated Effect of Hiring a Lawyer on the Probability of an Employer Victory, Final Offer Arbitration in New Jersey, 1978-1995

\section{Dependent Variable $=$ Employer Victory \\ Probit Estimates Change in Probability}

$\begin{array}{lcc}\text { Employer Hires a Lawyer } & \begin{array}{l}0.722^{*} \\ (0.124)\end{array} & 0.258^{*} \\ & & (0.042) \\ \text { Union Hires a Lawyer } & -0.630^{*} & -0.245^{*} \\ & (0.155) & (0.060) \\ & 0.291^{*} & 0.109^{*} \\ \text { Average of Final Offers } & (0.050) & (0.019) \\ & -354.8 & \\ \text { Log-Likelihood } & 620 & \\ \text { Observations } & & \\ \quad \text { Implications for the Arbitrator's Distribution of Preferred Wage Changes } \\ \text { Standard Deviation } & 3.44 \% & \\ \text { Mean Shift if Employer Hires a Lawyer } & -2.48 \% & \\ \text { Mean Shift if Union Hires a Lawyer } & 2.12 \%\end{array}$

Notes: Standard errors, clustered at the municipality level, reported in parentheses. The probit regression also includes 17 year dummies. The change in the probability of an employer victory associated with a change in the independent variable calculated at the means of the other explanatory variables.

*Statistically significant at the .05 significance level 


\section{Table 5}

\section{Percentage of Discharge Grievances Sustained (for the Union) in 755 Arbitrations, 1979-1982}

\section{Union Uses:}

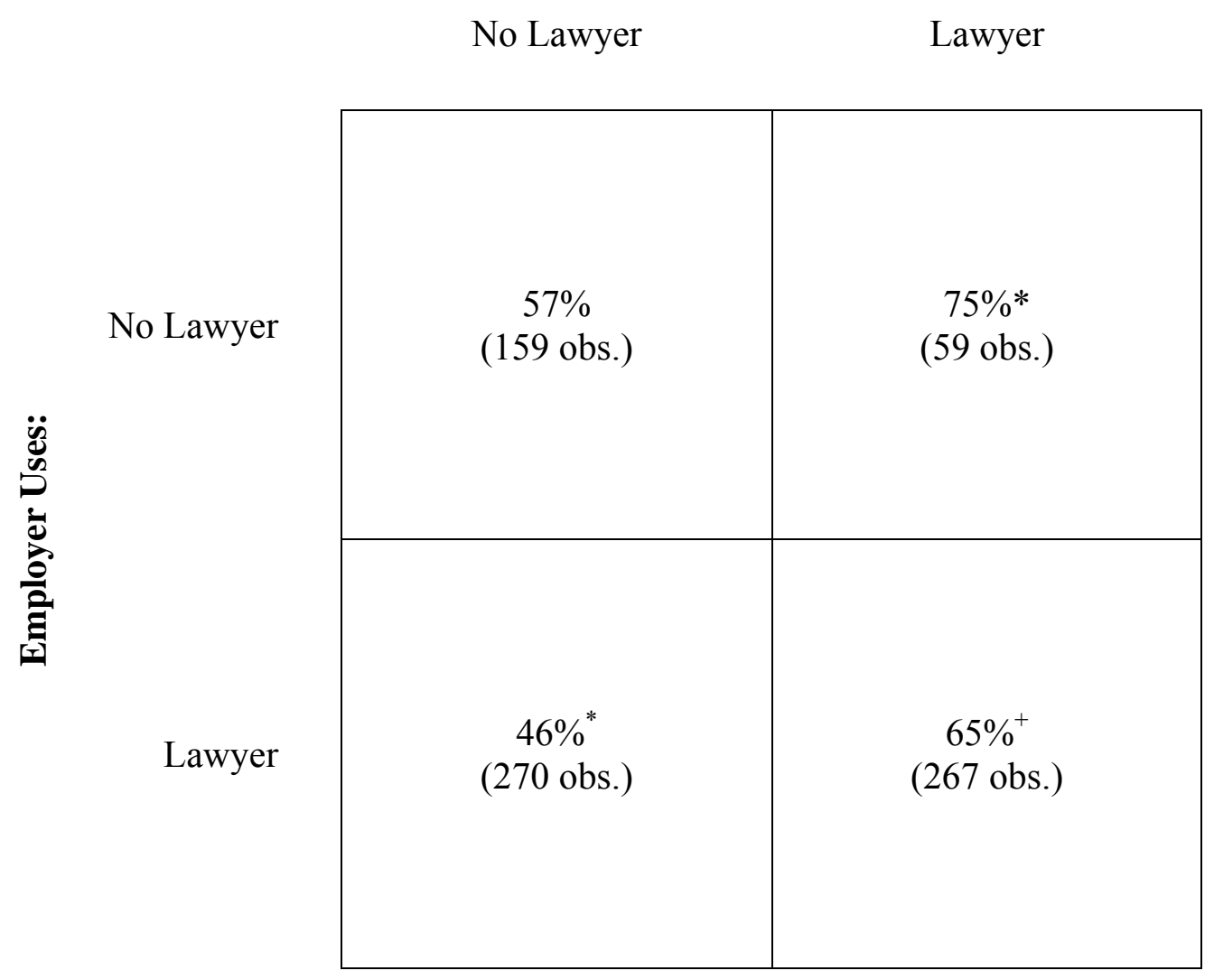

*Award rate is significantly different from the rate when neither party uses a lawyer (at the .05 significance level)

${ }^{+}$Award rate is not significantly different from the rate when neither party uses a lawyer (at the .05 significance level)

Source: Block and Stieber (1987) 


\section{Table 6}

Percentage of Plaintiff Claims (Debt Collection, Personal Injury, Breach of Contract, Property Damage) Awarded by Arbitrators in Pittsburgh

\section{Plaintiff Uses:}

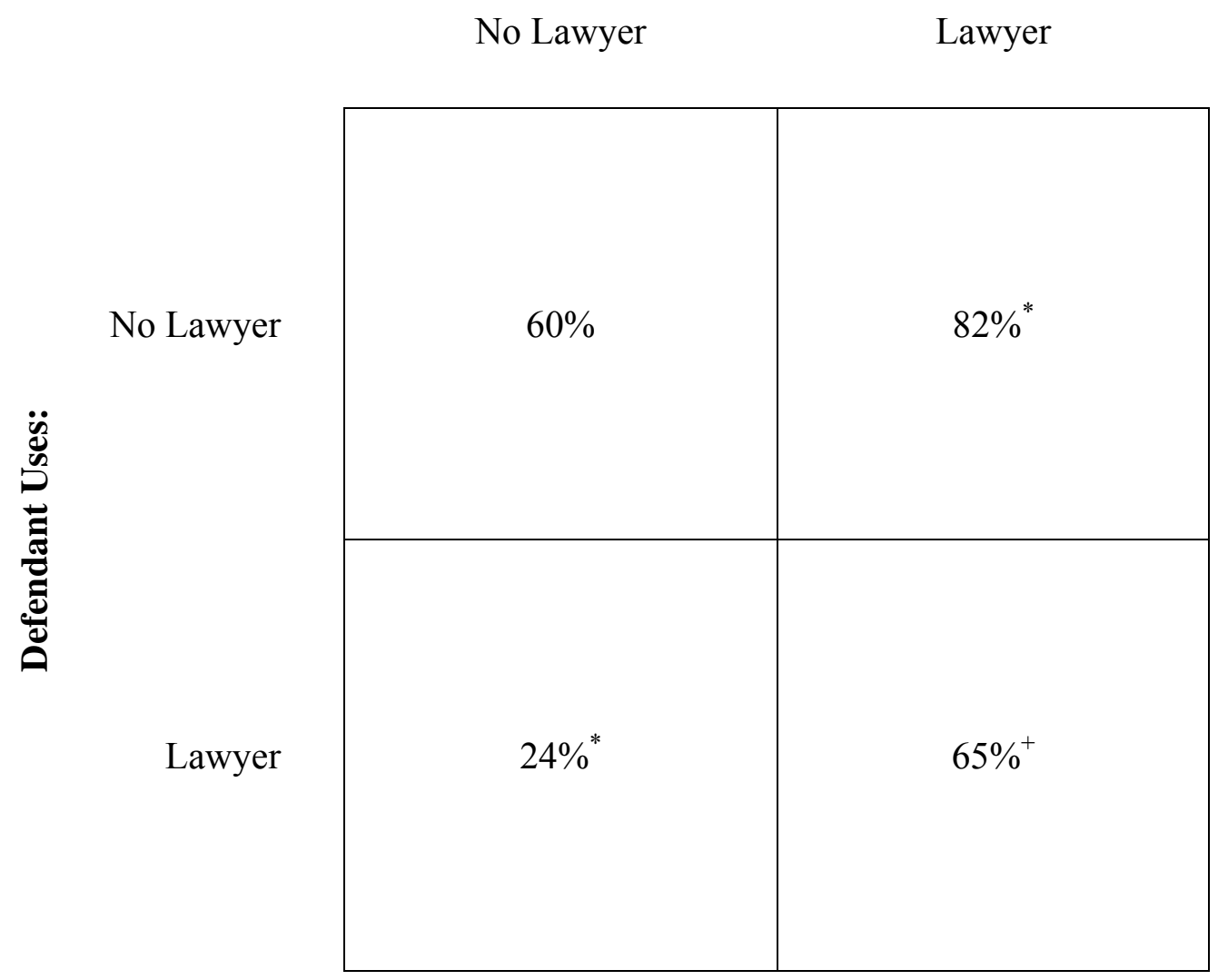

*Award rate is significantly different from the rate when neither party uses a lawyer (at the .05 significance level)

${ }^{+}$Award rate is not significantly different from the rate when neither party uses a lawyer (at the .05 significance level)

Source: Adler, Hensler, and Nelson (1983) 


\section{Table 7}

Percentage of Mothers Awarded Child Physical Custody in San Mateo and Santa Clara Counties, California, 1984-85

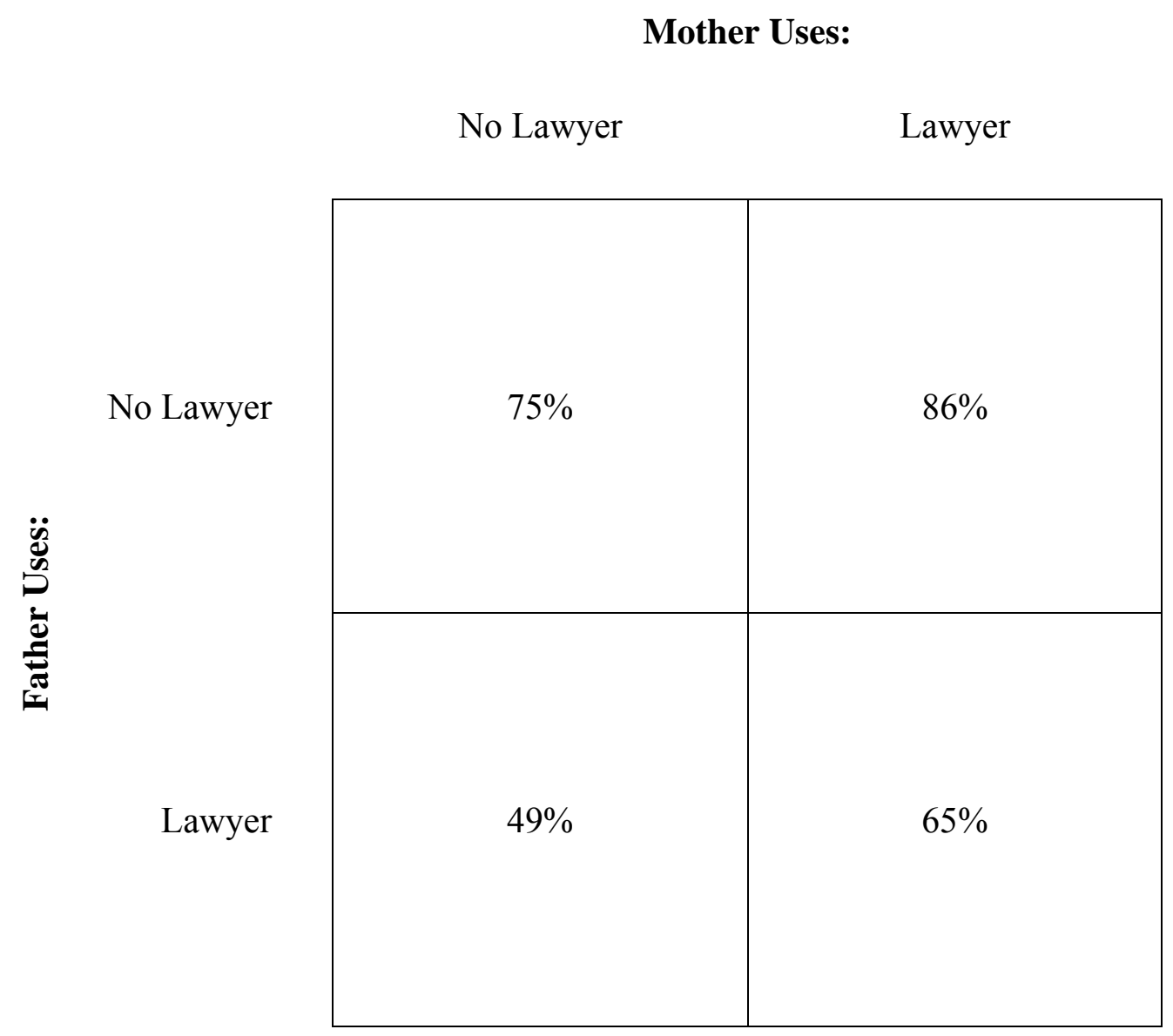

Source: Mnookin, Maccoby, Depha, and Albiston (1989). 


\section{Table 8}

Yearly Employer Victory Rate and the Difference in Lawyer Use, Final Offer Arbitration in New Jersey, 1978-1995

\section{Dependent Variable $=$ Employer Victory Rate in a Year OLS Estimate}

Difference in Lawyer Usage Rates

$0.47^{*}$

(0.16)

Adjusted R-squared

Observations
0.32

18

Notes: Standard errors reported in parentheses. Each observation represents a yearly average. Difference in lawyer usage rates is defined as the fraction of cases the employer uses a lawyer minus the fraction of cases the union uses a lawyer in a year.

*Statistically significant at the .05 significance level 


\section{Table 9}

The Moderating Effect of Lawyers on the Difference in Final Offers, Final Offer Arbitration in New Jersey, 1978-1995

\section{Dependent Variable $=$ Difference in Final Offers \\ OLS Estimates}

Employer Hires a Lawyer Interacted with:
$1978 \leq$ year $\leq 1983$
$-0.590 *$
$1984 \leq$ year $\leq 1989$
$(0.284)$
0.012
$(0.165)$
$1990 \leq$ year $\leq 1995$

Union Hires a Lawyer Interacted with:
$1978 \leq$ year $\leq 1983$
0.076
$1984 \leq$ year $\leq 1989$
$1990 \leq$ year $\leq 1995$
0.115
(0.208)
0.108
620

R-squared

Observations

Notes: Standard errors, clustered at the municipality level, reported in parentheses. The regression also includes time period dummies.

*Statistically significant at the .05 significance level 


\section{Figure 1}

Effect of the Union Hiring a Lawyer on the Distribution of Arbitrators' Preferred Awards

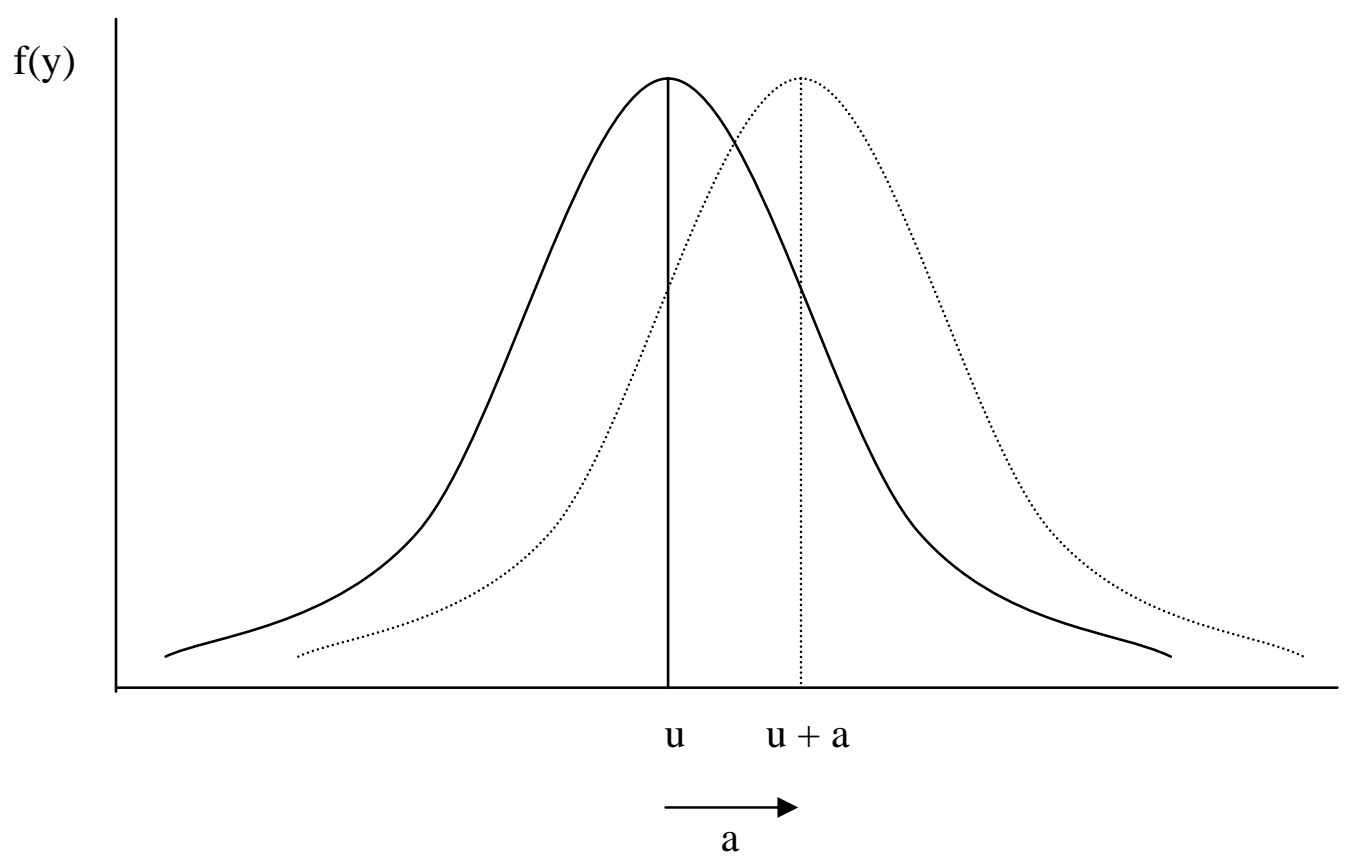

When the union hires a lawyer, the distribution of arbitrators' awards shifts by the quantity $a$ so that the mean award increases from $u$ to $u+a$. 
Figure 2

The Probability of an Employer Victory as a Function of the Final Offers

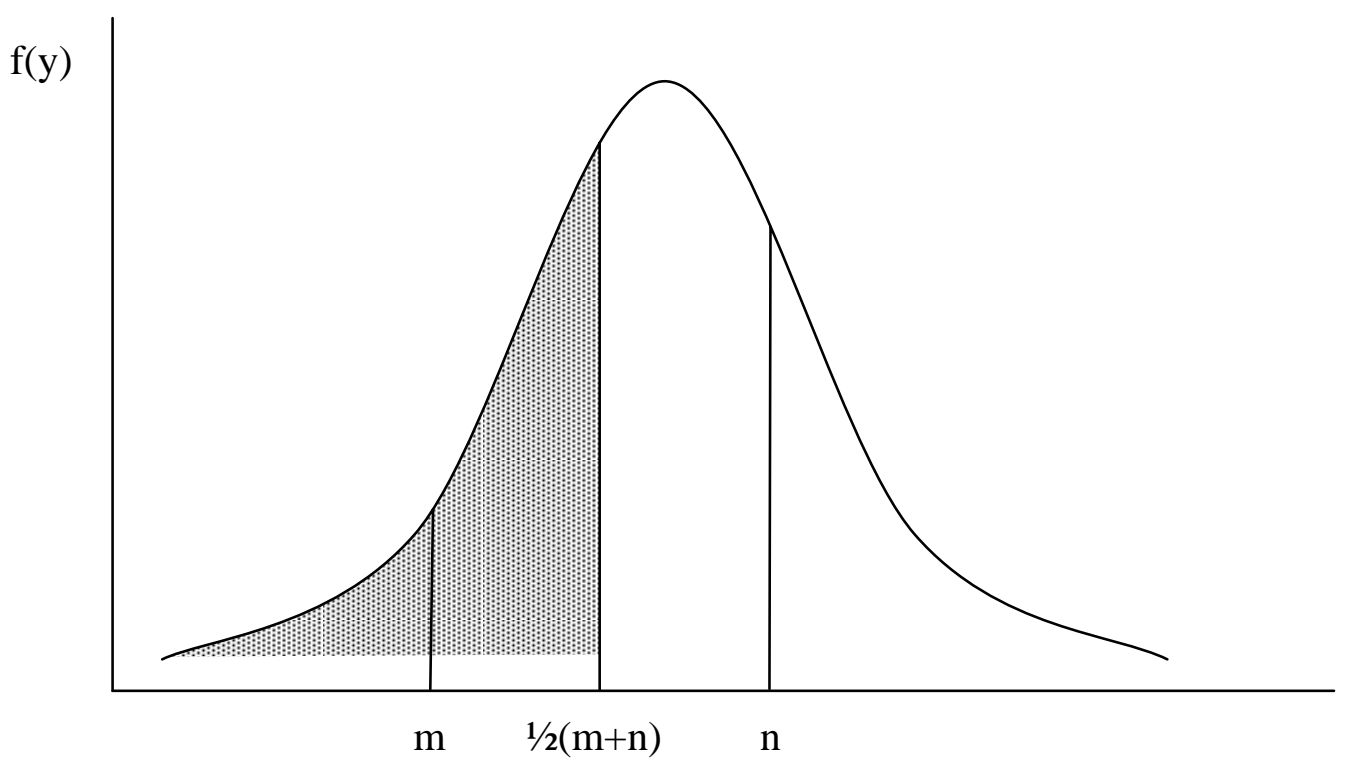

Shaded area represents the probability of an employer victory given the employer's final offer, $m$, and the union's final offer, $n$. 


\section{Figure 3}

\section{Effect of the Union Hiring a Lawyer on the Probability of an Employer Victory}

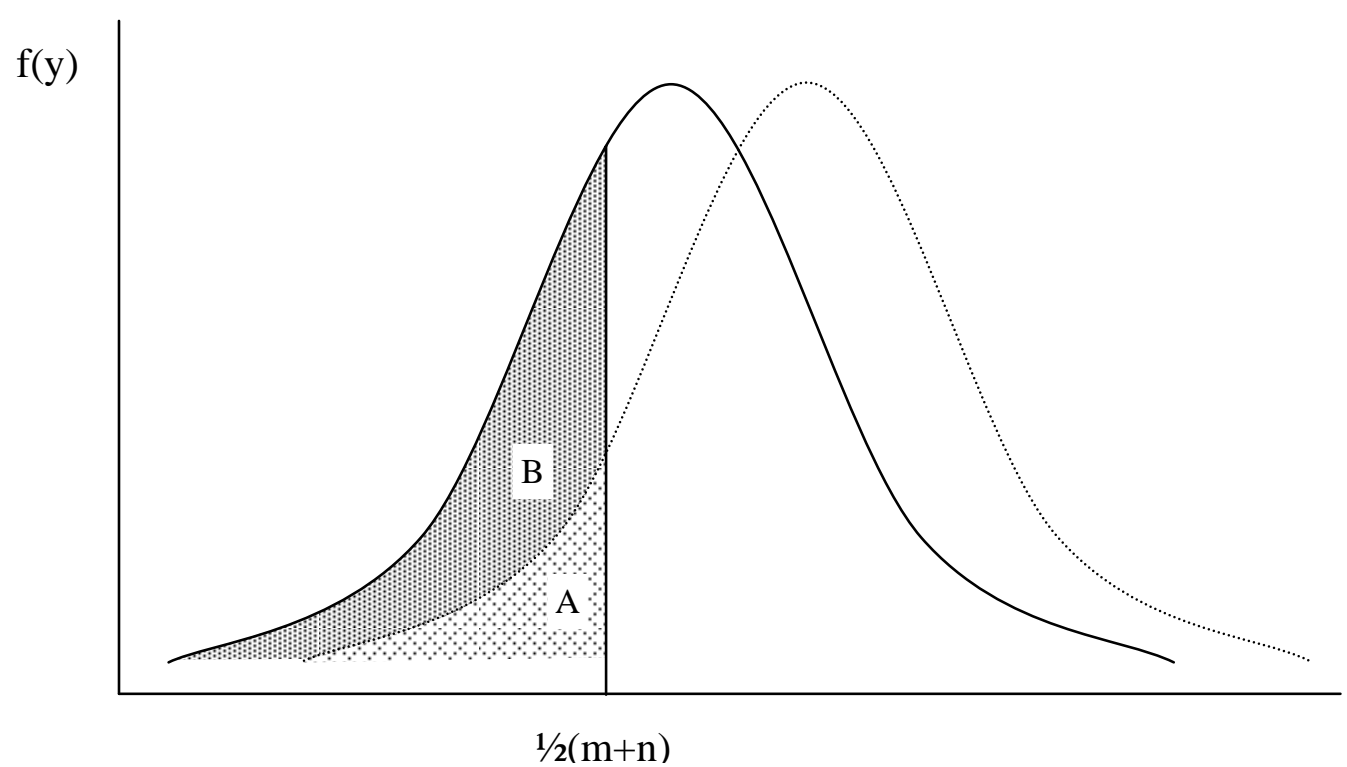

Area $A+B$ represents the probability of an employer victory for the set of final offers $m$ and $n$ if neither side hires a lawyer. Area $B$ represents the decrease in this probability if the union hires a lawyer but the employer does not for the same set of final offers (since area $A$ is the probability of an employer victory in this case). 
Figure 4

Employer Victory Rate and the Use of Lawyers by the Employer and Union,

Final Offer Arbitration in New Jersey, 1978-1995

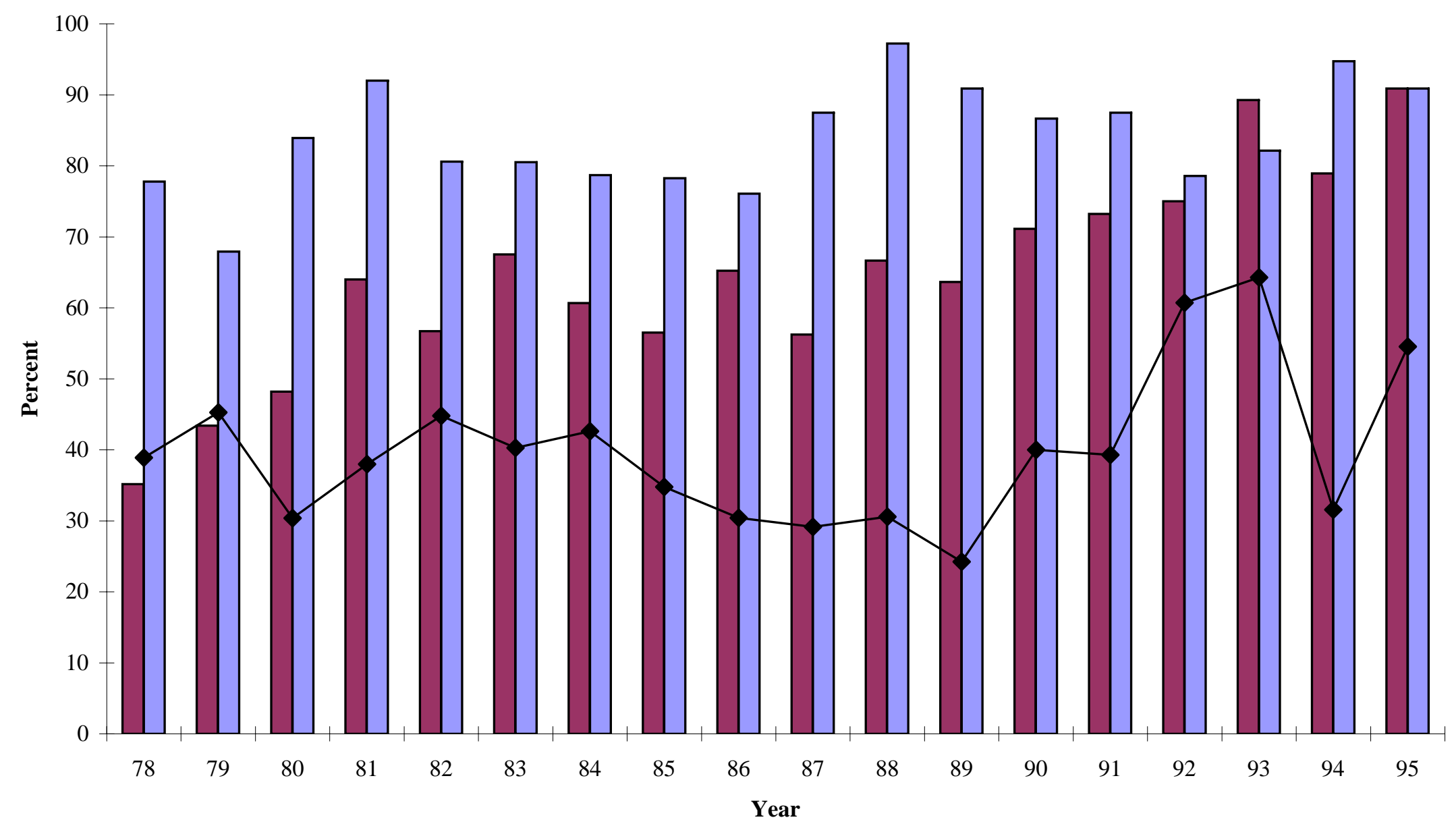

$\square$ Percent of Cases in which Employer Uses a Lawyer

Percent of Cases in which Union Uses a Lawyer

Percent of Employer Victories 
Figure 5

Lawyer Use Based on Prior Arbitration Experience,

Final Offer Arbitration in New Jersey, 1978-1995

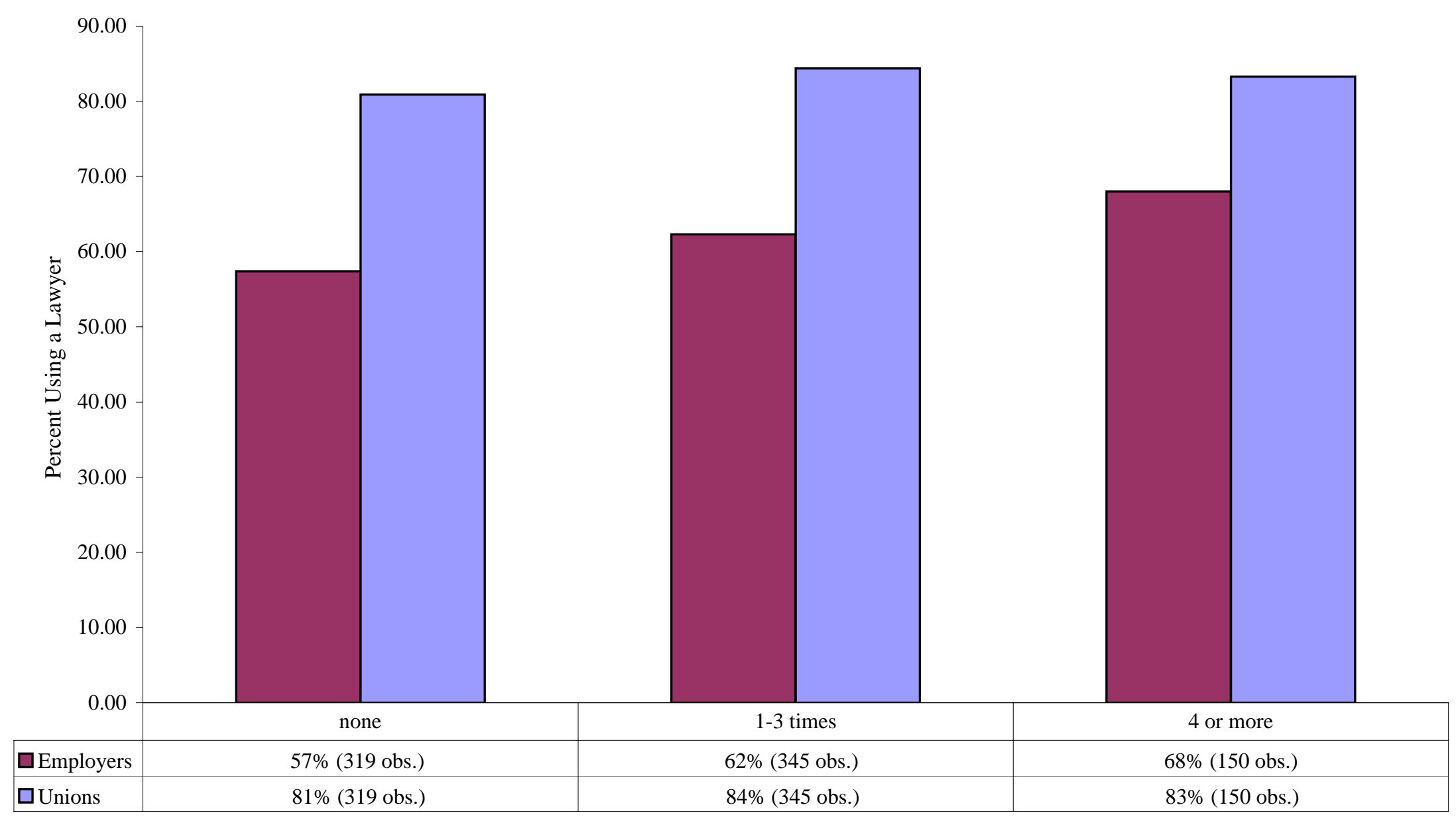

Number of Previous Times a Municipal Bargaining Unit Has Been to Arbitration 
Figure 6

Difference between the Union's and the Employer's Final Offers, Final Offer Arbitration in New Jersey, 1978-1995

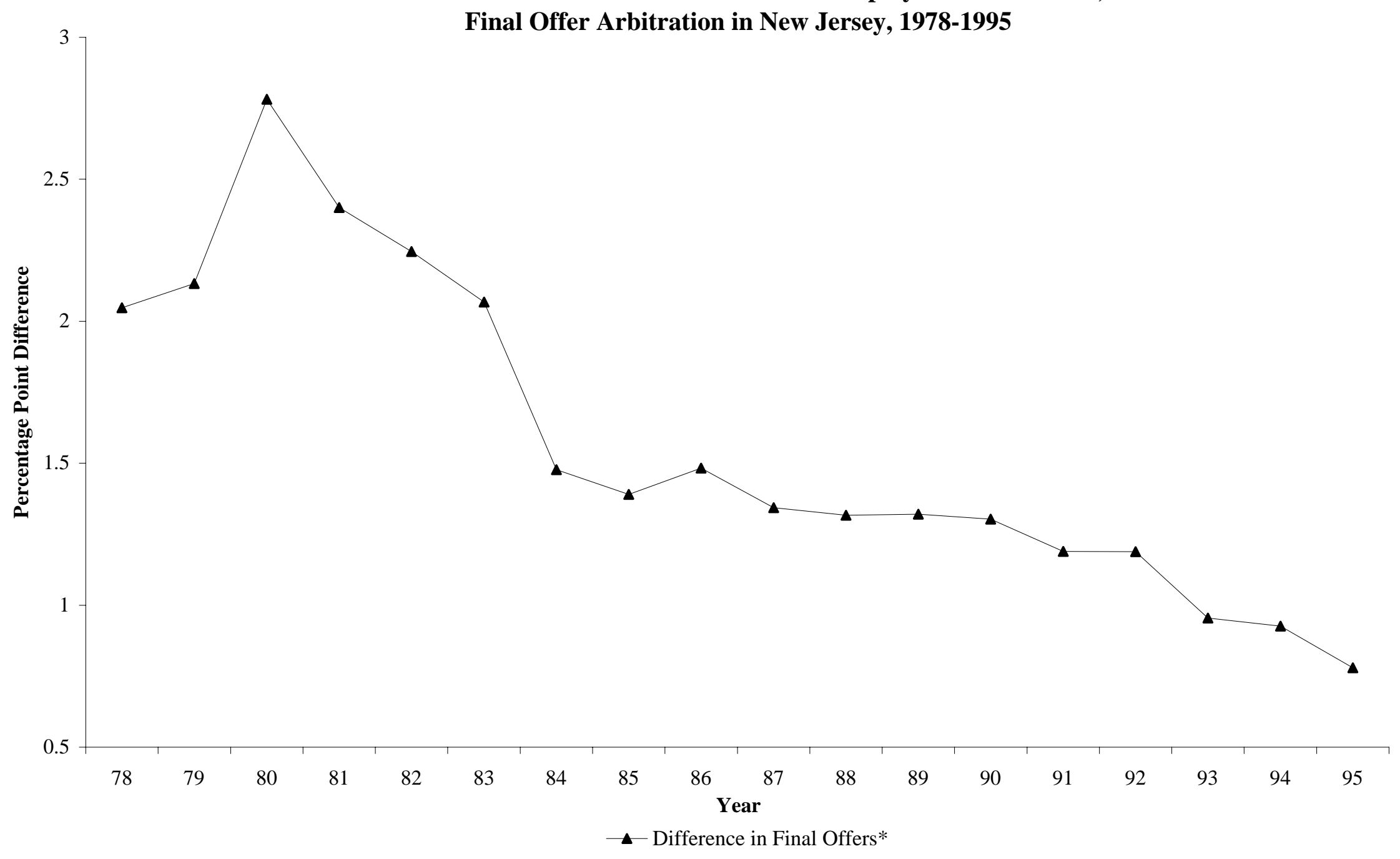

*Final offer of the union minus final offer of the employer. 